Jap J. M. Sc. \& Biol., 15, 153-163, 1962

\title{
STUDIES ON SENDAI VIRUS INFECTION IN LABORATORY MICE
}

\author{
Hideo FUKUMI, HiROMICHI MIZUTANI, YASUE TAKEUCHI \\ Department if Bacteriology, National Institute of Health, Tokyo \\ YosHIO TAJIMA \\ Department of Animal Infections, Institute for Infectious \\ Diseases, University of Tokyo \\ KIYOSHI IMAIZUMI, TOSHIO TANAKA \\ Department of Animal Diseases, National Institute of \\ Health, Tokyo \\ AND JUN-ICHI KANEKO \\ Hikari Laboratory, Takeda Pharmaceutical Company, LTD
}

(Received: July 30th, 1962)

A hemagglutinating virus was reported to be frequently isolated from laboratory mice by us in Japan (Fukumi et al, 1954). This virus was later proposed to be called HVM (hemagglutinating virus of mice) by us, but as several independent names were adopted by several groups of investigators and more confusion was apt to occur, a committee was established by the Society of Japanese Virologists to control such confusion. This committee finally agreed to propose the name HVJ (hemagglutinating virus of Japan) for the virus in question. This virus is however, widely called Sendai virus in countries outside of Japan since Jensen et al.'s publication (Jensen et al., 1956), where they proposed to call it as influenza virus D. Now it seems fairly well accepted that the virus belongs to Myxovirus parainfluenzae type 1, though there is still some reservation (Fukumi and Nishikawa, 1961).

As this virus has been considerably widely distributed among laboratory mice, it has often caused disturbances in experiments in which intranasal inoculations of laboratory mice are employed, especially experiments dealing with mouse passages of influenza and some other viruses. This situation prompted us to conduct experiments concerned with epidemiology and some other features of Sendai virus infections in laboratory mice.

\section{EXPERIMENTAL MATERIALS AND METHODS}

Isolation of Sendai virus from laboratory mice: Preliminary experiments were carried out to decide which of the two inoculation techniques, amniotic and allantoic inoculations, is prefe-

福見秀雄・水谷裕迪・武内安恵（国立予防衛生研究所細菌第一部）

田嶋嘉雄（伝染病研究所獣疫部）

今泉清・田中利雄（国立予防衛生研究所獣疫部）

金子順一（武田薬工光工場） 
rable to recover Sendai virus from infected laboratory mice. Embryonated eggs of 8 days', 11 days' and 15 days' incubations were inoculated with 7G3 strain of Sendai virus either by amniotic or by allantoic inoculation, then virus growth was estimated by titrating hemagglutinin in amniotic or in allantoic fluid every day after inoculation. From this experiment, it has been evidenced that the most rapid growth and the highest hemagglutination titer are obtained with the embryonated eggs of 8 days' incubation inoculated into amniotic cavity. From these experimental results, it was decided to use intra-amniotic inoculation into 8 days' embryonated eggs for virus isolation. Sterile broth was intranasally instilled to laboratory mice to be tested for harboring Sendai virus and after approximately 4 days, their lungs were removed and ground with glass powder in a morter to be suspended in broth. The resulting suspensions were inoculated into the amniotic cavity of embryonated eggs. Four days after the inoculation, amniotic and allantoic fluids were harvested from the inoculated eggs and subjected to hemagglutination in order to know if Sendai virus (or some other hamagglutinating virus if any), were successfully isolated. When a virus was isolated, it was subjected to hemagglutination inhibition reaction by using Sendai virus immune rooster serum to confirm that it was Sendai virus.

Sendai virus strains employed: MN strain of Sendai virus was isolated from a laboratory mouse in 1953 and employed in most of our previous works of this virus (Fukumi et al., 1954). The 7G3 strain was isolated during the early period of the present investigations, and consequently subjected to only a few egg passages.

Serological examination of Sendai virus antibody in laboratory mice: The presence of Sendai virus antibody was examined by hemagglutination inhibition reaction by employing Sendai virus $\mathrm{MN}$ strain as antigen. It was at first investigated what treatments would be most suitable to eliminate non-specific inhibitors in mouse serum. After heating at $56^{\circ} \mathrm{C}$ for 30 minutes, a portion of serum was treated with RDE overnight, or with $\mathrm{KIO}_{4}$ (addition of $\mathrm{M} / 100 \mathrm{KIO}_{4}$ in an equal amount or in three volumes to sera) overnight and hemagglutination inhibition titers obtained for such treated portions of sera were compared with those for the remaining portions of the sera which were not treated. The results showed that there was no recognizable difference in HI value between sera treated by either RDE or $\mathrm{KIO}_{4}$ solution and those subjected to no treatment, and it seemed that non-specific inhibitors did not cause a serious effect upon the results even though no such treatment was especially made to mouse sera, if the HI titers of $\geq 1: 16$ alone would be taken into consideration. However, sometimes in the estimation of hemagglutination inhibition titers the results were obscured by natural hemagglutinins for chick red cells in some of the mouse sera, therefore, the mouse sera to be tested were absorbed by chick red cells (addition of $5 \%$ red cells in an equal amount to serum) immediately before the estimation, but no treatment was made for elimination of non-specific inhibitors.

Artificial infection of laboratory mice with Sendai virus: Mice were put in a closed animal cage and Sendai virus suspension of a certain virus concentration was sprayed into it with a nebulizer under a constant pressure for 15 minutes. The mice, after the treatment, were removed from it and kept in another new cage for further observation.

\section{EXPERIMENTAL RESULTS}

\section{Observations in Two Lines of Laboratory Mice Bred in the National Institute of Health, Tokyo.}

The two lines of laboratory mice, dd/y and GPC lines, being bred in the National Institute of Health, Tokyo, were kept under observation and 25 to 30 mice (4 weeks of age) in average were drawn randomly from each of the flocks for virological and serological examinations. These mice were bled 4 or 5 days after the intranasal inoculation of broth for provocation and at the same time the lungs were removed from them for Sendai virus isolation. The sera drawn from them were subjected to serological examination of Sendai virus antibody. The experimental results are shown in a summarized form in Figs. 1 and 2. In these two flocks of mouse lines, there were, from June 1957 to December 1959, at least two occasions, when prevalence of Sendai virus infection was recognized. In 1957, examinations of mice were made only twice, namely in June and July for either the mouse flock of $\mathrm{dd} / \mathrm{y}$ line or that of GPC, and 


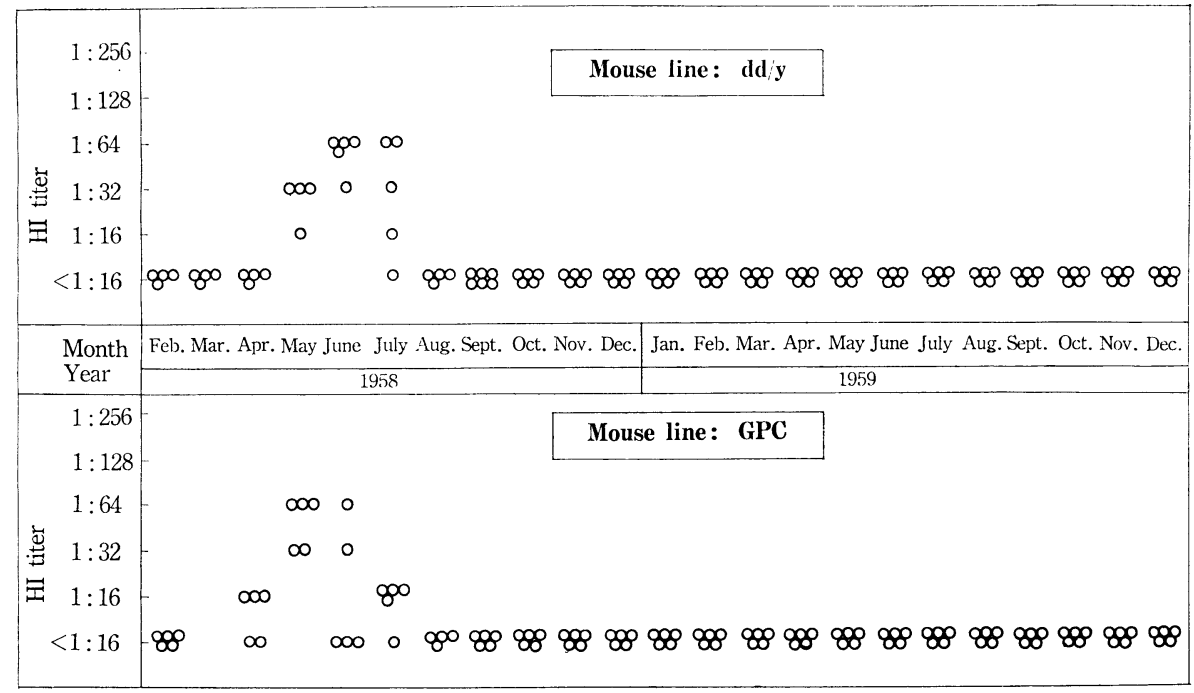

Fig. 1. Sendai virus antibody survey in two lines of mice (dd/y and GPC) during the period from February 1958 to December 1959.

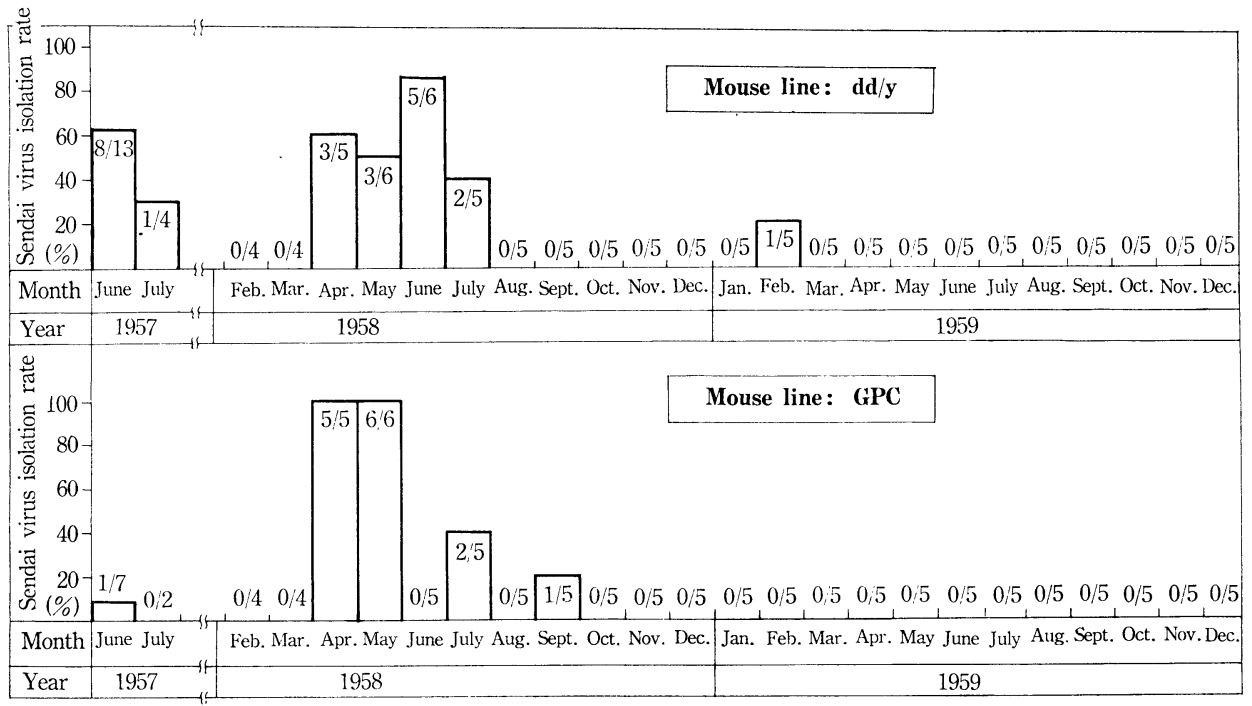

Fig. 2. Sendai virus isolation rate in two lines of mice (dd/y and GPC) during the period from June 1957 to December 1959.

Sendai virus was isolated in both the occasions for the former and only in the earlier occasion for the latter. At that time, serological examinations were unfortunately not carried out. For the dd/y mice, Sendai virus was recovered from them in April, May, June, July and September, 1958, while in the GPC mice, successful isolations of Sendai virus were made in April, May, July and September, 1958. These results were well confirmed by the serological findings. In the $\mathrm{dd} / \mathrm{y}$ mice, one of the 5 mouse pools was found infected with Sendai virus in February, 1959, but it did not reflect in the sero- 
logical finding. In conclusion, it is quite certain that there were epidemics of Sendai virus infection among both the flocks of mice in almost the same period namely from April to July, 1958. It is very probable, though there was no clear evidence, that the Sendai virus prevalences in both the flocks had a common vehicle or at least they were two expressions of one and the same event, but no such mechanism was clarified. At any rate, the breeding places for both the mouse lines were located very near to each other and furthermore, there was certainly frequent human and material contacts between them.

\section{Relationship between Sendai Virus Isolation and Antibody Titer against This Virus in the Laboratory Mice during the Epidemic Period.}

During the investigation of the epidemic of Sendai virus infection among the mice in the National Institute of Health, a small experiment was carried out to see if there was any relationship between virus isolation and Sendai virus antibody titer in the animals. Eight mice, 5 from GPC line and 3 from dd/y, were picked up for checking their virus harboring on one hand, and for titrating Sendai virus antibody titer in their sera on the other hand. The result is shown in Table 1. Virus isolation was successful only in those mice which had no measurable antibody. However, since the number of mice subjected to the survey was very small, the conclusion should be reserved for further investigation of a larger scale.

\section{Serological Survey of Sendai Virus Infection in Laboratory Mice from Various Farms in Japan.}

Laboratory mice were forwarded to our laboratory from various mouse breeding farms in order to know how widely Sendai virus infections are spread in bred mice. The mice sent to us were in average 5 weeks old and bled as soon as possible after the arrival at our laboratory, and sera of 5 or 6 mice were pooled together to be submitted to Sendai virus antibody titration. The results are summarized in Table 2 . As can be seen there, there were mice possessing Sendai virus antibody in Saitama Branch of Nippon General Institute for Experimental Animals and Nishigaki Farm for Experimental Animals at Tachikawa (Tokyo). In the former, mice were bled on January 15, 1958, therefore there was presumably more or less prevalence of Sendai virus infection at least a little before that time. In the latter, however, the mice were bled several times in the year of 1958 , and mice possessing Sendai virus antibody were detected for total 5 serum pools; that seems to indicate strongly that Sendai virus infection had been prevailing among the mice there from time to time during a fairly long period.

In another line of our experiments, sera of laboratory mice were collected in the Hikari mouse farm of Takeda Pharmceutical Company (Yamaguchi Prefecture) from mice of various breeding lines at various intervals, mostly bred there but a few purchased from outside, and submitted to Sendai virus antibody survey. The result is shown in Table 3. Mice possessing Sendai virus antibody were detected thrice during the survey period, among total 34 chances, and these mice were found among the ones bred there, and the time, when these mice were bred, were September, and December, 1958 and January 1959. Thus it may be concluded that in this mouse farm also, Sendai virus infection occurred from time to time during the survey period. 
Table 1. Reversed correlation between Sendai virus isolation and antibody titer

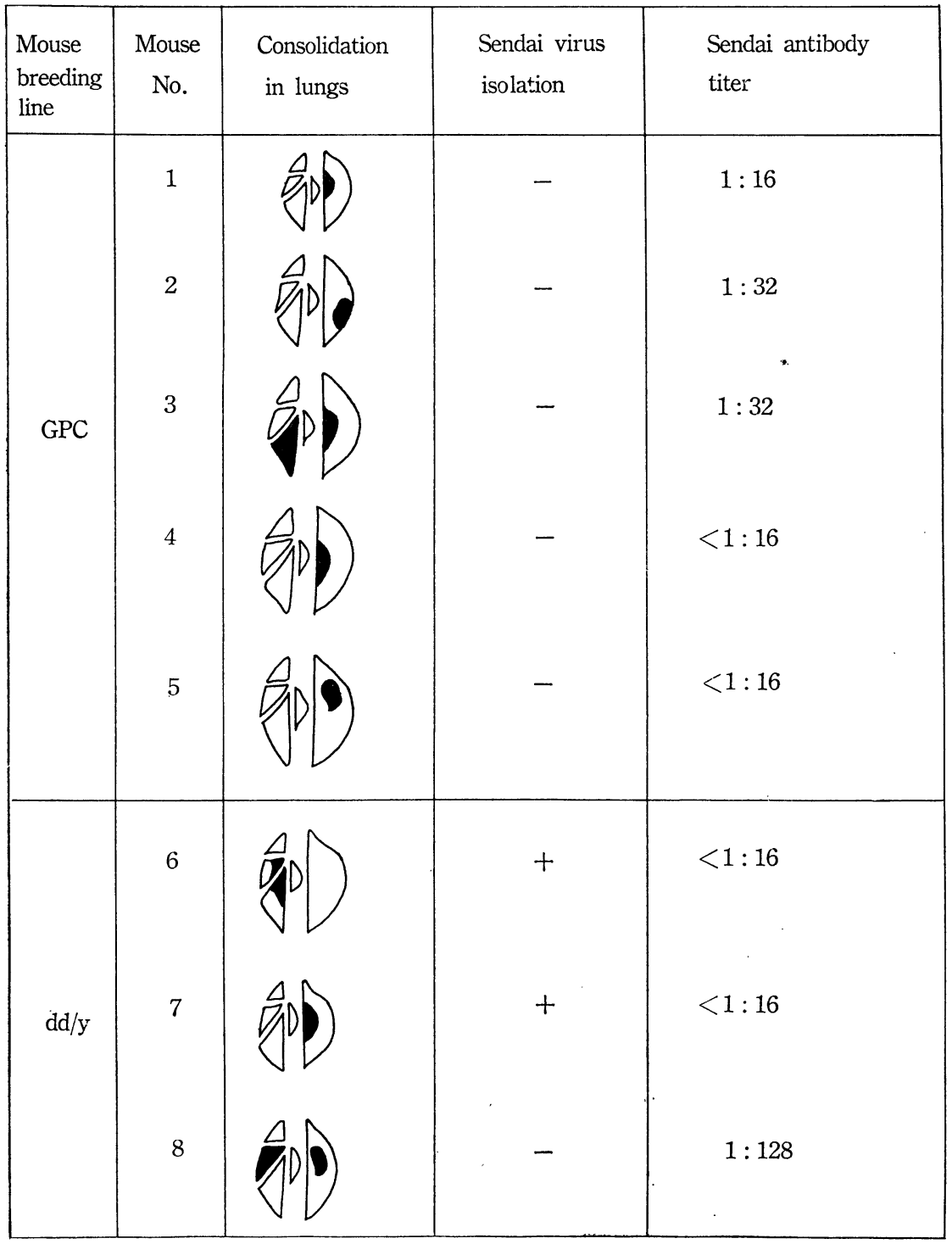

\section{Experimental Infection of Laboratory Mice with Sendai Virus.}

Mice within one day after birth, mice of age of four weeks and of eight weeks were subjected to experiments. MN strain of Sendai virus, subjected to 3 mouse, and 8 egg passages, was employed for the experiments. In each age group, infected mice, mice not-infected but kept together with the infected mice in a single cage, and control mice which were neither infected nor kept together with the infected mice were marked. 
Table 2. Sendai virus antibody survey for mice raised in various institutes and farms in Japan

\begin{tabular}{|c|c|c|c|c|}
\hline $\begin{array}{l}\text { Agency which } \\
\text { supplied the mice } \\
\text { for the experiment }\end{array}$ & $\begin{array}{l}\text { Place where } \\
\text { the mice were } \\
\text { raised }\end{array}$ & $\begin{array}{l}\text { Date of serum } \\
\text { drawing }\end{array}$ & $\begin{array}{l}\text { Serum pool } \\
\text { No. }\end{array}$ & $\begin{array}{c}\text { Sendai antibody } \\
\text { titer }\end{array}$ \\
\hline \multirow{2}{*}{$\begin{array}{l}\text { Nippon Institute } \\
\text { for Medical Animals } \\
\text { and Materials }\end{array}$} & $\begin{array}{l}\text { Saitama } \\
\text { Prefecture }\end{array}$ & $\begin{array}{l}\text { 22 December } \\
1958\end{array}$ & $\begin{array}{l}1 \\
2 \\
3 \\
4 \\
5\end{array}$ & $\begin{array}{l}<1: 16 \\
<1: 16 \\
<1: 16 \\
<1: 16 \\
<1: 16\end{array}$ \\
\hline & $\begin{array}{l}\text { Tokyo } \\
\text { Prefecture }\end{array}$ & $\begin{array}{l}22 \text { December } \\
1858\end{array}$ & $\begin{array}{r}6 \\
7 \\
8 \\
9 \\
10\end{array}$ & $\begin{array}{l}<1: 16 \\
<1: 16 \\
<1: 16 \\
<1: 16 \\
<1: 16\end{array}$ \\
\hline $\begin{array}{c}\text { Kanamaru Animal } \\
\text { Handler }\end{array}$ & $\begin{array}{l}\text { Tokyo } \\
\text { Prefecture }\end{array}$ & $\begin{array}{l}\text { 23 December } \\
1958\end{array}$ & $\begin{array}{l}1 \\
2 \\
3\end{array}$ & $\begin{array}{l}<1: 16 \\
<1: 16 \\
<1: 16\end{array}$ \\
\hline \multirow{2}{*}{$\begin{array}{l}\text { Nippon General } \\
\text { Institute for } \\
\text { Experimental } \\
\text { Animals }\end{array}$} & $\begin{array}{l}\text { Gumma } \\
\text { Prefecture }\end{array}$ & $\begin{array}{l}\text { 15 January } \\
1959\end{array}$ & $\begin{array}{r}1 \\
2 \\
3 \\
4 \\
5 \\
6 \\
7 \\
8 \\
9 \\
10\end{array}$ & $\begin{array}{l}<1: 16 \\
<1: 16 \\
<1: 16 \\
<1: 16 \\
<1: 16 \\
<1: 16 \\
<1: 16 \\
<1: 16 \\
<1: 16 \\
<1: 16\end{array}$ \\
\hline & $\begin{array}{l}\text { Saitama } \\
\text { Prefecture } \\
\text { (Kasukabe } \\
\text { District) }\end{array}$ & $\begin{array}{l}\text { 15 January } \\
1959\end{array}$ & $\begin{array}{l}11 \\
12 \\
13 \\
14 \\
15 \\
16 \\
17\end{array}$ & $\begin{array}{r}<1: 16 \\
<1: 16 \\
<1: 16 \\
<1: 16 \\
1: 16 \\
1: 16 \\
<1: 16\end{array}$ \\
\hline $\begin{array}{c}\text { Central Institute } \\
\text { for Experimental } \\
\text { Animals }\end{array}$ & $\begin{array}{l}\text { Tokyo } \\
\text { Prefecture } \\
\text { (Nishitama } \\
\text { District) }\end{array}$ & $\begin{array}{l}21 \text { January } \\
1959\end{array}$ & $\begin{array}{r}1 \\
2 \\
3 \\
4 \\
5 \\
6 \\
7 \\
8 \\
9 \\
10 \\
11 \\
12\end{array}$ & $\begin{array}{l}<1: 16 \\
<1: 16 \\
<1: 16 \\
<1: 16 \\
<1: 16 \\
<1: 16 \\
<1: 16 \\
<1: 16 \\
<1: 16 \\
<1: 16 \\
<1: 16 \\
<1: 16\end{array}$ \\
\hline $\begin{array}{l}\text { Nishigaki Farm } \\
\text { for Experimental } \\
\text { Animals }\end{array}$ & $\begin{array}{l}\text { Tokyo } \\
\text { Prefecture }\end{array}$ & $\begin{array}{l}\text { from time to } \\
\text { time in } 1958\end{array}$ & $\begin{array}{r}1 \\
2 \\
3 \\
4 \\
5 \\
6 \\
7 \\
8 \\
9 \\
10\end{array}$ & $\begin{array}{r}<1: 16 \\
1: 16 \\
1: 16 \\
<1: 16 \\
<1: 16 \\
1: 32 \\
1: 32 \\
1: 16 \\
<1: 16 \\
<1: 16\end{array}$ \\
\hline
\end{tabular}


Table 3. Sendai virus antibody survey for mice of various lines in Hikari

Laboratory of Takeda Pharmaceutical Company, LTD. (Yamaguchi Prefecture) during the period from 1958 to early 1959

\begin{tabular}{|c|c|c|}
\hline Mouse breeding line & Date of serum collection & $\begin{array}{l}\text { Sendai virus antibody titer } \\
\text { of pooled sera }\end{array}$ \\
\hline $\mathrm{dd}-\mathrm{T}$ & $\begin{aligned} 15 & \text { September } 1958 \\
13 & \text { October } 1958 \\
6 & \text { December } 1958 \\
21 & \text { January } 1959\end{aligned}$ & $\begin{array}{r}<1: 16 \\
<1: 16 \\
1: 16 \\
<1: 16\end{array}$ \\
\hline $\mathrm{C} 3 \mathrm{H}$ & 15 September 1958 & $<1: 16$ \\
\hline $\mathrm{C} 37 \mathrm{BR} / \mathrm{cd}$ & $\begin{aligned} & 15 \text { September } 1958 \\
& 13 \text { October } 1958 \\
& 6 \text { December } 1958 \\
& 21 \text { January } 1959\end{aligned}$ & $\begin{aligned} & 1: 16 \\
&< 1: 16 \\
&< 1: 16 \\
&<1: 16\end{aligned}$ \\
\hline $\mathrm{A}$ & $\begin{array}{l}15 \text { September } 1958 \\
13 \text { October } 1958 \\
21 \text { January } 1959\end{array}$ & $\begin{array}{l}<1: 16 \\
<1: 16 \\
<1: 16\end{array}$ \\
\hline $\mathrm{db} a / 2$ & $\begin{aligned} 15 & \text { September } 1958 \\
6 & \text { December } 1958 \\
21 & \text { January } 1959\end{aligned}$ & $\begin{array}{l}<1: 16 \\
<1: 16 \\
<1: 16\end{array}$ \\
\hline CF1 & $\begin{aligned} & 15 \text { September } 1958 \\
& 13 \text { October } 1958 \\
& 6 \text { December } 1958 \\
& 21 \text { January } 1959\end{aligned}$ & $\begin{array}{l}<1: 16 \\
<1: 16 \\
<1: 16 \\
<1: 16\end{array}$ \\
\hline AKR & $\begin{aligned} 13 & \text { September } 1958 \\
6 & \text { December } 1958 \\
21 & \text { January } 1959\end{aligned}$ & $\begin{array}{l}<1: 16 \\
<1: 16 \\
<1: 16\end{array}$ \\
\hline $\mathrm{C} 57 \mathrm{BL} / 6$ & $\begin{aligned} 15 & \text { September } 1958 \\
6 & \text { December } 1958 \\
21 & \text { January } 1959\end{aligned}$ & $\begin{array}{r}<1: 16 \\
<1: 16 \\
1: 16\end{array}$ \\
\hline $\begin{array}{l}\text { Mice purchased from } \\
\text { Gifu Farm } \\
\text { (Gifu Prefecture) }\end{array}$ & $\begin{array}{l}15 \text { September } 1958 \\
13 \text { October } 1958 \\
6 \text { December } 1958\end{array}$ & $\begin{array}{l}<1: 16 \\
<1: 16 \\
<1: 16\end{array}$ \\
\hline $\begin{array}{l}\text { Mice purchased from } \\
\text { Osaka Kyoei Farm } \\
\text { (Osaka Prefecture) }\end{array}$ & $\begin{aligned} 15 & \text { September } 1958 \\
6 & \text { December } 1958 \\
21 & \text { January } 1959\end{aligned}$ & $\begin{array}{l}<1: 16 \\
<1: 16 \\
<1: 16\end{array}$ \\
\hline
\end{tabular}

In the first experiment, an allantoic fluid infected with Sendai virus, having an infective titer of $10^{-6.5} \mathrm{ID}_{50} / 0.2 \mathrm{cc}$ and hemagglutination titer of $1: 10^{2.4}$, was inhaled in a sprayed form for 15 minutes. The death of the mice was recorded as shown in Table 4. The mice within a day of age were all found dead at least 7 days after infection, while those not infected but kept in the same cage with the infected ones died at a more delayed time, namely 12 days after infection. For the mice 4 weeks old, three among 10 infected died while only one died among eight mice kept in the same cage with the infected. There was however no death among the animals 8 weeks old, either among the infected, or among those kept together with the infected.

The second experiment was carried out in almost the same schedule, here Sendai virus suspension made by emulsifying infected mouse lungs at $10 \%$ was employed for spraying. The emulsion had an infectivity of $10^{-1} \mathrm{ID}_{50} / 0.2 \mathrm{cc}$ for embryonated eggs. The experimental result was essentially the same as the previous one, as shown in Table 5, though the infectivity titer of the infecting virus material employed was much less in this experiment than in the previous one.

In the first experiment cited above, daily change of body weight was followed for 
Table 4. Death after the spraying infection of Sendai virus in three age-groups and in the contact group of mice. (Virus material for spraying: MN strain 3 mouse and 8 egg passaged, Egg $\left.\mathrm{ID}_{50}: 10^{6.5} / 0.2 \mathrm{cc}\right)$

\begin{tabular}{|c|c|c|c|c|c|c|c|c|c|c|c|c|c|c|c|c|c|c|}
\hline \multirow{2}{*}{ Age } & \multirow{2}{*}{$\begin{array}{l}\text { Cage } \\
\text { No. }\end{array}$} & \multirow{2}{*}{ Treatment } & \multirow{2}{*}{$\begin{array}{l}\text { Total } \\
\text { mice } \\
\text { used }\end{array}$} & \multicolumn{15}{|c|}{ Survival after the Infection (days) } \\
\hline & & & & 1 & 2 & 3 & 4 & 5 & 6 & 7 & 8 & 9 & 10 & 11 & 12 & 13 & 141 & 15 \\
\hline \multirow{5}{*}{$\begin{array}{l}\text { Suckling } \\
\text { mice }\end{array}$} & & $\int$ infected & 5 & 5 & 5 & 5 & 5 & 5 & 2 & 0 & & & & & & & & \\
\hline & & contact & 4 & 4 & 4 & 4 & 4 & 4 & 4 & 4 & 4 & 4 & 3 & 2 & 0 & & & \\
\hline & \multirow{2}{*}{2} & $\int$ infected & 6 & 6 & 5 & 5 & 5 & 3 & 0 & & & & & & & & & \\
\hline & & $\{$ contact & 3 & 3 & 3 & 3 & 3 & 3 & 3 & 3 & 3 & 3 & 2 & 1 & 0 & & & \\
\hline & 3 & normal control & 5 & 5 & 5 & 5 & 5 & 5 & 5 & 5 & 5 & 5 & 5 & 5 & 5 & 5 & 5 & 5 \\
\hline \multirow{5}{*}{$\begin{array}{l}4 \text { weeks } \\
\text { old mice }\end{array}$} & \multirow[b]{2}{*}{1} & $\{$ infected & 5 & 5 & 5 & 5 & 5 & 5 & 5 & 5 & 5 & 5 & 5 & 4 & 4 & 4 & 3 & 3 \\
\hline & & contact & 3 & 3 & 3 & 3 & 3 & 3 & 3 & 3 & 3 & 3 & 3 & 3 & 3 & 2 & 2 & 2 \\
\hline & & $\{$ infected & 5 & 5 & 5 & 5 & 5 & 5 & 5 & 5 & 5 & 5 & 5 & 5 & 5 & 4 & 4 & 4 \\
\hline & & contact & 5 & 5 & 5 & 5 & 5 & 5 & 5 & 5 & 5 & 5 & 5 & 5 & 5 & 5 & 5 & 5 \\
\hline & 3 & normal control & 5 & 5 & 5 & 5 & 5 & 5 & 5 & 5 & 5 & 5 & 5 & 5 & 5 & 5 & 5 & 5 \\
\hline \multirow{5}{*}{$\begin{array}{l}8 \text { weeks } \\
\text { old mice }\end{array}$} & \multirow{2}{*}{1} & $\{$ infected & 5 & 5 & 5 & 5 & 5 & 5 & 5 & 5 & 5 & 5 & 5 & 5 & 5 & 5 & 5 & 5 \\
\hline & & I contact & 3 & 3 & 3 & 3 & 3 & 3 & 3 & 3 & 3 & 3 & 3 & 3 & 3 & 3 & 3 & 3 \\
\hline & & $\{$ infected & 4 & 4 & 4 & 4 & 4 & 4 & 4 & 4 & 4 & 4 & 4 & 4 & 4 & 4 & 4 & 4 \\
\hline & & I control & 3 & 3 & 3 & 3 & 3 & 3 & 3 & 3 & 3 & 3 & 3 & 3 & 3 & 3 & 3 & 3 \\
\hline & 3 & normal control & 5 & 5 & 5 & 5 & 5 & 5 & 5 & 5 & 5 & 5 & 5 & 5 & 5 & 5 & 5 & 5 \\
\hline
\end{tabular}

Table 5. Death after the spraying infection of Sendai virus in three age-groups and in the contact group of mice. (Virus material for spraying: MN strain ten percent monse lung suspension, Egg $\mathrm{ID}_{50}: 10^{1.0} / \mathrm{cc}$ )

\begin{tabular}{|c|c|c|c|c|c|c|c|c|c|c|c|c|c|c|c|c|c|c|}
\hline \multirow{2}{*}{ Age } & \multirow{2}{*}{$\begin{array}{l}\text { Cage } \\
\text { No. }\end{array}$} & \multirow{2}{*}{ Treatment } & \multirow{2}{*}{$\begin{array}{l}\text { Total } \\
\text { mice } \\
\text { used }\end{array}$} & \multicolumn{15}{|c|}{ Survival after the infection (days) } \\
\hline & & & & 1 & 2 & 3 & 4 & 5 & 6 & 7 & 8 & & & 11 & & 13 & 141 & 15 \\
\hline \multirow{5}{*}{$\begin{array}{l}\text { Suckling } \\
\text { mice }\end{array}$} & \multirow{2}{*}{1} & $\{$ infected & 7 & 7 & 7 & 7 & 7 & 7 & 7 & 3 & 0 & & & & & & & \\
\hline & & contact & 3 & 3 & 3 & 3 & 3 & 3 & 3 & 3 & 3 & 3 & 3 & 3 & 3 & 2 & 0 & \\
\hline & \multirow{2}{*}{2} & $\{$ infected & 5 & 5 & 5 & 5 & 5 & 5 & 3 & 0 & & & & & & & & \\
\hline & & contact & 3 & 3 & 3 & 3 & 3 & 3 & 3 & 3 & 3 & 3 & 2 & 0 & & & & \\
\hline & 3 & normal control & 5 & 5 & 5 & 5 & 5 & 5 & 5 & 5 & 5 & 5 & 5 & 5 & 5 & 5 & 5 & 5 \\
\hline \multirow{5}{*}{$\begin{array}{l}4 \text { weeks } \\
\text { old mice }\end{array}$} & & $\{$ infected & 5 & 5 & 5 & 5 & 5 & 5 & 5 & 5 & 5 & 4 & 4 & 3 & 3 & 3 & 3 & 2 \\
\hline & & l contact & 3 & 3 & 3 & 3 & 3 & 3 & 3 & 3 & 3 & 3 & 3 & 3 & 2 & 2 & 2 & 2 \\
\hline & \multirow[t]{2}{*}{2} & $\{$ infected & 5 & 5 & 5 & 5 & 5 & 5 & 5 & 5 & 5 & 5 & 5 & 5 & 5 & 5 & 5 & 4 \\
\hline & & l contact & 3 & 3 & 3 & 3 & 3 & 3 & 3 & 3 & 3 & 3 & 3 & 3 & 3 & 3 & 3 & 3 \\
\hline & 3 & normal control & 5 & 5 & 5 & 5 & 5 & 5 & 5 & 5 & 5 & 5 & 5 & 5 & 5 & 5 & 5 & 5 \\
\hline \multirow{5}{*}{$\begin{array}{l}8 \text { weeks } \\
\text { old mice }\end{array}$} & & $\int$ infected & 5 & 5 & 5 & 5 & 5 & 5 & 5 & 5 & 5 & 5 & 5 & 5 & 5 & 5 & 4 & 4 \\
\hline & & l contact & 3 & 3 & 3 & 3 & 3 & 3 & 3 & 3 & 3 & 3 & 3 & 3 & 3 & 3 & 3 & 3 \\
\hline & & $\int$ infected & 5 & 5 & 5 & 5 & 5 & 5 & 5 & 5 & 5 & 5 & 5 & 5 & 5 & 5 & 5 & 4 \\
\hline & & 1 contact & 3 & 3 & 3 & 3 & 3 & 3 & 3 & 3 & 3 & 3 & 3 & 3 & 3 & 3 & 3 & 3 \\
\hline & 3 & normal control & 5 & 5 & 5 & 5 & 5 & 5 & 5 & 5 & 5 & 5 & 5 & 5 & 5 & 5 & 5 & 5 \\
\hline
\end{tabular}


a group of infected, a group of mice kept together with the infected mice in a single cage and the control group of mice not infected and without contact with the infected mice, for the mice less than a day of age. The result is given in Fig. 3.

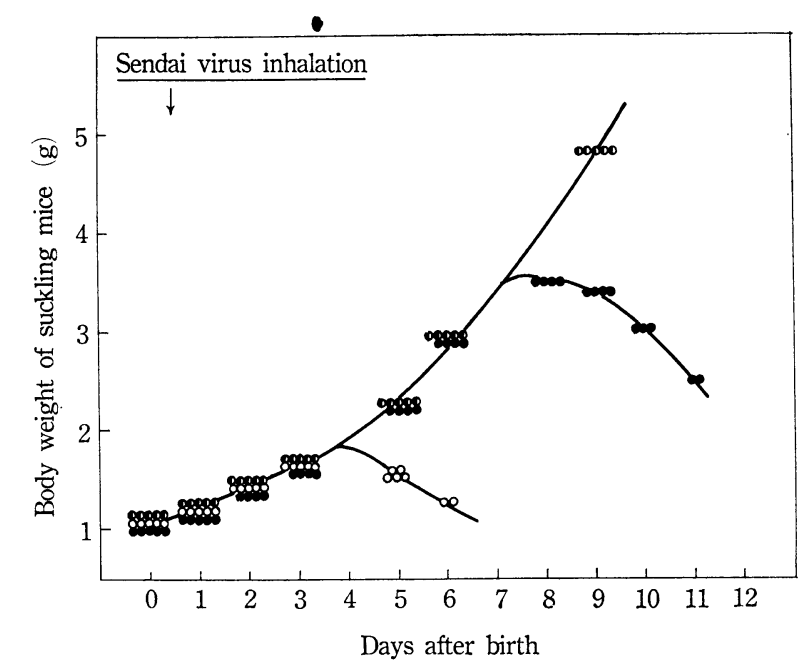

$\bigcirc$ : Suckling mice infected with Sendai virus by inhalation.

: Suckling mice not infected but living together with infected ones.

D : Control suckling mice, not infected, and no contact with infected ones.

Fig. 3. Body weight of suckling mice infected with Sendai virus and of the suckling mice kept in contact with those infected one in a single cage.

The body weight of the infected suckling mice began to decrease after a certain incubation period namely approximately 4 days after virus inhalation, while in the case of those mice kept with the infected ones in a single cage, the decrease of their body weight started about 7 days after the virus inhalation of the infected ones. It is very evident that the Sendai virus infection spreads from the infected to the healthy mice by cohabitation in a single cage, whatever the mechanism of the virus spread is. It can not, however, be said at this stage of investigation which of the mechanisms, namely contact, droplet or some other vehicle of infection, is acting for the spread of virus infection. By the way, it seems reasonable to consider that the infected mice are at the most contagious stage when their body weight begins to decrease, because the mice infected due to cohabitation with the first-infected ones were very likely to catch infection at the time approximately 4 days (incubation period) before the onset of their body weight decrease that, grossly speaking, corresponds to the period when the first-infected ones began to lose their body weight.

\section{DISCUSSION}

It seems to be very interesting to know how Sendai virus is ecologically behaving in the natural world. As far as the authors' surveys are concerned, this virus is 
pathogenic only for the mouse and a few other species of experimental animals, and the virus appears to be living its natural life among these animals. But, it should be said its true feature has not even grossly been elucidated yet.

The present publication shows that when mouse flocks were kept under observation for Sendai virus infection, prevalence of the infection was sometimes recognized among them in a certain length of time (approximately 3 to 4 months long). During such an epidemic period, the virus was recovered from apparently health mice at a very high rate, and at approximately the same time or a little later, Sendai virus antibody of fairly high titer was observed in sera of a large proportion of the flock mice. This prevalence of the infection disappeared spontaneously or, in other words, with no special measure for its elimination, and for long time thereafter no infection was recognized at all. Coincidental with this, no Sendai virus antibody was detected among the mice when the virus prevalence was not recognized.

The virus may probably have been introduced from outside, but what seems to be peculiar is why the epidemic, if it may be called as such, did disappear spontaneously from inside. One of likely explanations is that it is the over-whelming of the antibody which eradicated the virus infection, or at least temporarily suppressed its appearance.

The prevalence of the Sendai virus infection was observed during almost the same period in the two mouse flocks which were being separately raised. It seems very likely, judged from the circumstantial evidences, that the two incidences were of a common basis. The separation did not seem to be satisfactory for preventing the spread of the Sendai virus infection from one to the other. There were free human communications and common use of some equipments, and materials, and it is considered that these mutual human and material communications were sufficient to transmit the agent among mouse flocks. What is the most important mechanism (s) for virus transmission in intercolonial comminicability of infection remains, however, to be elucidated.

\section{SUMMARY}

1. Flocks of pure line mice were subjeted to observations for Sendai virus infection for about two years.

2. During the observation period, there was at least once a prevalence of Sendai virus infection recognized in the flocks.

3. During the prevalence of the infection, a large proportion of the animals acquired antibody against Sendai virus.

4. The prevalence of infection lasted for approximately 3 months and subsided spontaneously with no apparently infected mice left.

\section{REFERENCES}

Fukumi, H. \& Nishikawa, F. (1961): Comparative studies of Sendai and HA 2 viruses. Jap. J. M. Sc. \& Biol., 14, 109-120.

Fukumi, H., Nishikawa, F., Sugryama, T., Yamaguchi, Y., Nanba, J., Matuura, T. \& OIKAWA, R. (1959): An epidemic due to HA 2 virus in an elementary school in Tokyo. Jap. J. M. Sc. \& Biol., 12, 307-317.

Fukumi, H., Nishikawa, F. \&. Kitayama, T. (1954): A pneumotropic virus from mice causing hemagglutination. Jap. J. M. Sc. \& Biol., 7, 345-365. 
Jensen, K. E., Minuse, E. \& Ackermann, W. W. (1955): Serological evidence of American experience with newborn pneumonitis virus (Type Sendai). J. Immunol., 75, 71-77.

NishikaWA, F. \& FUKUMI, H. (1954): Shape and size of hemagglutinating virus of mice (HVM). Jap. J. M. Sc. \& Biol., 7, 513-522. 